\title{
Progestin withdrawal at parturition in the mare
}

\author{
Erin L Legacki ${ }^{1}$, C J Corbin , B A Ball², M Wynn², S Loux², S D Stanley ${ }^{3}$ and A J Conley ${ }^{1}$ \\ ${ }^{1}$ Department of Population Health and Reproduction, School of Veterinary Medicine, University of California, \\ Davis, California, USA, ${ }^{2}$ Gluck Equine Research Center, Department of Veterinary Science, University of Kentucky, \\ Lexington, Kentucky, USA and ${ }^{3}$ Department of Molecular Biosciences, School of Veterinary Medicine, \\ University of California, Davis, California, USA
}

Correspondence should be addressed to A J Conley; Email: ajconley@ucdavis.edu

\begin{abstract}
Mammalian pregnancies need progestogenic support and birth requires progestin withdrawal. The absence of progesterone in pregnant mares, and the progestogenic bioactivity of $5 \alpha$-dihydroprogesterone (DHP), led us to reexamine progestin withdrawal at foaling. Systemic pregnane concentrations (DHP, allopregnanolone, pregnenolone, $5 \alpha$-pregnane-3 $\beta, 20 \alpha$-diol ( $3 \beta, 20 \alpha \mathrm{DHP})$, $20 \alpha$-hydroxy-5 $\alpha$-dihydroprogesterone $(20 \alpha \mathrm{DHP})$ ) and progesterone) were monitored in mares for 10 days before foaling $(n=7)$ by liquid chromatography-mass spectrometry. The biopotency of dominant metabolites was assessed using luciferase reporter assays. Stable transfected Chinese hamster ovarian cells expressing the equine progesterone receptor (ePGR) were transfected with an MMTV-luciferase expression plasmid responsive to steroid agonists. Cells were incubated with increasing concentrations (0-100 $\mathrm{nM}$ ) of progesterone, $20 \alpha \mathrm{DHP}$ and $3 \alpha, 20 \beta \mathrm{DHP}$. The concentrations of circulating pregnanes in periparturient mares were (highest to lowest) $3 \alpha, 20 \beta$ DHP and $20 \alpha \mathrm{DHP}(800-400 \mathrm{ng} / \mathrm{mL}$ respectively), DHP and allopregnanolone (90 and $30 \mathrm{ng} / \mathrm{mL}$ respectively), and pregnenolone and progesterone (4-2 $\mathrm{ng} / \mathrm{mL}$ ). Concentrations of all measured pregnanes declined on average by $50 \%$ from prepartum peaks to the day before foaling. Maximum activation of the ePGR by progesterone occurred at $30 \mathrm{nM} ; 20 \alpha \mathrm{DHP}$ and $3 \alpha, 20 \beta \mathrm{DHP}$ were significantly less biopotent. At prepartum concentrations, both $20 \alpha \mathrm{DHP}$ and $3 \alpha, 20 \beta \mathrm{DHP}$ exhibited significant ePGR activation.

Progestogenic support of pregnancy declines from 3 to 5 days before foaling. Prepartum peak concentrations indicate that DHP is the major progestin, but other pregnanes like $20 \alpha \mathrm{DHP}$ are present in sufficient concentrations to play a physiological role in the absence of DHP. The authors conclude that progestin withdrawal associated with parturition in mares involves cessation of pregnane synthesis by the placenta.

Reproduction (2016) 152 323-331
\end{abstract}

\section{Introduction}

Mammalian pregnancy is maintained by the physiological effects of progestins (Conley \& Reynolds 2014) and parturition is believed to occur principally, or in large part, as a result of withdrawal of that support (Thorburn \& Challis 1979, Smith 2007, Zakar \& Hertelendy 2007, Renthal et al. 2015). In many species, the physiological withdrawal before parturition is due to a decline in available progesterone (Nathanielsz 1998, Norwitz 1999, Jenkin \& Young 2004, Mitchell \& Taggart 2009), the pregnane that is generally considered the most potent endogenous progestin and that decrease is apparent in systemic blood. Studies in women (Pieber et al. 2001) and mice (Condon et al. 2003, Mendelson \& Condon 2005) revealed that birth is not invoked by a decline in systemic progesterone but involves a decrease in expression or function of the classic nuclear progesterone receptors (Kastner et al. 1990) in target tissues (Conneely et al. 2003, Mesiano et al. 2011) such as myometrium. In horses, the endocrinology of pregnancy is more complex (Conley 2016, Legacki et al. 2016) than other animals and the mechanisms initiating parturition are a matter of speculation (Thorburn 1993, Silver 1994, Conley \& Neto 2008, Fowden et al. 2008). When rigorous methods were applied, progesterone disappeared from the circulation and was absent throughout much of the second half of gestation in mares (Short 1959). The hormone profile includes a variety of other $5 \alpha$-reduced pregnanes, metabolites of progesterone (Moss et al. 1979, Hamon et al. 1991, Holtan et al. 1991). The immediate $5 \alpha$-reduced metabolite of progesterone, $5 \alpha$-dihydroprogesterone (DHP) is bioactive based on its competition binding with progesterone in vitro (Jewgenow \& Meyer 1998, Chavatte-Palmer et al. 2000). In the first study on bioactivity in the horse, we showed that DHP stimulated endometrial growth and secretion, and that equine pregnancy could be maintained by 
DHP in the absence of progesterone (Scholtz et al. 2014). Further, we developed an in vitro bioassay and showed that DHP was as biopotent as progesterone in activating the equine progesterone receptor but not the human progesterone receptor (Scholtz et al. 2014). These data proved that DHP alone is sufficient to support equine pregnancies, but sampling was infrequent in late gestation and events around parturition were not well characterized (Scholtz et al. 2014, Legacki et al. 2016).

Previous studies investigating the changes in the concentration of progesterone and other pregnanes in periparturient mares have yielded conflicting data, depending on the pregnane measured. Discrepancies among studies are due to the differences in frequency of blood sampling as well as the analysis of steroids. Immunoassays are typically unable to distinguish progesterone from other, mainly $5 \alpha$-reduced, pregnanes, whose levels increase in late equine gestation (Ganjam et al. 1975, Holtan et al. 1975b, 1991). Holtan and coworkers (1991) recognized the need for careful analysis of steroid profiles using frequent sampling around the time of parturition in mares. They were the first to perform mass spectrometry to monitor multiple pregnanes throughout pregnancy. Their data indicated a peak in pregnane concentrations 2 days before foaling, which was followed by a decline. They concluded that frequent sampling is required to confirm these patterns near term and it is not known whether these compounds are biologically active or are simply the metabolic end products (Holtan et al. 1991). The lack of progestogenic activity of the major $5 \alpha$-reduced pregnane metabolites has only been inferred from competitive binding studies (Jewgenow \& Meyer 1998, Chavatte-Palmer et al. 2000). Previous attempts to show bioactivity in vitro were unsuccessful (Ousey et al. 2000). Some recently developed methods measure multiple pregnanes and other steroids throughout pregnancy with accuracy and specificity (Legacki et al. 2016) using liquid chromatography-tandem mass spectrometry (LC-MS/ MS). The method included pregnenolone, the universal steroid substrate, which was predicted to provide information on changes in the overall rate of pregnane synthesis at parturition. Holtan and coworkers detected pregnenolone in samples taken from periparturient mares but did not measure (or report) its concentrations (Holtan et al. 1991). This study combines a detailed analysis of multiple pregnanes in samples taken daily until foaling with a direct assessment of the bioactivity of those present in the highest concentrations to more comprehensively investigate progestin withdrawal in parturient mares.

\section{Materials and methods}

Animal experiments were approved by the Institutional Animal Use and Care Advisory Committee at the University of California, Davis and the University of Kentucky, in accordance with the Guide for the Care and Use of Agricultural Animals in Agricultural Research and Teaching. Blood samples were taken from pregnant mares stabled at the University of California, Davis (UCD) in the 2015 foaling season and the University of Kentucky, Lexington (UKL) in the 2014 season. Mares in Lexington $(n=3)$ were mixedbreed light horse, aged $9.5 \pm 2.2$ years and gestation period was $330.0 \pm 6.8$ days. Mares sampled in Davis $(n=4)$ were all quarter horses, aged $8.8 \pm 0.9$ years and gestation period was $344.8 \pm 2.6$ days. For analysis, day -1 was designated as the last sample taken before foaling. Thus, samples taken on the day of, but still before, foaling were designated as day -1 samples, but if taken after foaling on that day they were designated as day 0 samples. Only one blood sample per day was analyzed per mare. Plasma samples were stored at $-20^{\circ} \mathrm{C}$ for analysis by liquid chromatography-tandem mass spectrometry (LC-MS/MS). Negative control plasma was charcoal-stripped to remove endogenous steroids and similarly stored at $-20^{\circ} \mathrm{C}$ until use.

\section{Steroid analysis by liquid chromatography-tandem mass spectrometry (LC-MS/MS)}

\section{Standards and solutions}

Standards were purchased from Steraloids (Newport, RI):

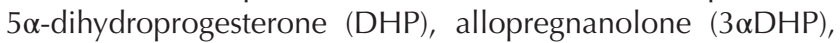

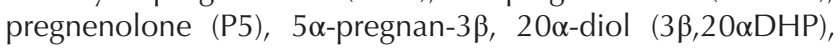
$20 \alpha$-hydroxy- $5 \alpha$-dihydroprogesterone $(20 \alpha \mathrm{DHP})$, progesterone and $\mathrm{d} 9$-progesterone (P4-d9). A master mix of all reference standards was prepared and diluted in methanol $(10,1,0.1$ and $0.01 \mathrm{ng} / \mathrm{mL}$ ). Methanol and water were of HPLC grade and obtained from Burdick and Jackson (Muskegon, MI, USA). Formic acid and methyl tert-butyl ether were of ACS grade and obtained from EMD (Gibbstown, NJ, USA).

\section{Sample preparation}

Samples were extracted according to the method developed and described by Legacki and coworkers (2016). Briefly, the P4-d9 internal standard was added to all plasma samples and the samples were extracted with methyl tert-butyl ether (1:5). Calibrators and quality control samples were prepared in charcoal-stripped plasma. Calibrators ranged from 0.1 to $100 \mathrm{ng} / \mathrm{mL}$ and four levels of quality control (QC) samples (0.6, 1.5. 20 and $80 \mathrm{ng} / \mathrm{mL}$ ) were prepared along with the samples. The plasma samples were shaken for $15 \mathrm{~min}$ and centrifuged at $3000 \mathrm{~g}$ for $5 \mathrm{~min}$. The resulting supernatant was transferred into a $12 \times 75$ glass tube and dried using a Zymark TurboVap concentrator (Hopkinton, MA, USA) at $45^{\circ} \mathrm{C}$ with $\mathrm{N} 2$. Samples were reconstituted with $200 \mu \mathrm{L}$ of 50:50 water and methanol. Quantitation of analytes was determined by linear regression analysis of the ratio of analyte area to the area of designated internal standard. Tandem mass spectral detection was developed using a Bruker EVOQ Triple Quadrupole Mass Spectrometer (Billerica, MA, USA). Calculations were made using the Bruker software. A minimum of six-point calibration curve and a maximum of ten points were used depending on the concentration of each analyte. 


\section{Method}

The LC-MS/MS method used was developed and described previously (Legacki et al. 2016). Briefly, reverse-phase gradient separation was performed on an Agilent UHPLC C18 analytical column $(2.1 \times 50 \mathrm{~mm}, 1.8 \mu \mathrm{mps})$ with two mobile phases delivered at $0.4 \mathrm{~mL} / \mathrm{min}$, an injection volume of $20 \mu \mathrm{L}$ and a column temperature of $40^{\circ} \mathrm{C}$. Mobile phase $\mathrm{A}$ and $\mathrm{B}$ were water with $0.2 \%$ formic acid and methanol respectively. An elution gradient was held at $40 \%$ B for the first $0.2 \mathrm{~min}, 40-60 \% \mathrm{~B}$ from 0.2 to $1 \mathrm{~min}, 60-80 \%$ B from 1 to $10 \mathrm{~min}, 80-90 \%$ B from 10.0 to $10.1 \mathrm{~min}, 90 \%$ B from 10.1 to $11.1 \mathrm{~min}, 90-40 \%$ from 11.1 to $11.2 \mathrm{~min}$ and $40 \% \mathrm{~B}$ until $13.10 \mathrm{~min}$. Ionization was achieved using an atmosphericpressure chemical ionization (APCI) source. Tandem mass spectral detection was accomplished using a Bruker EVOQ. Detection and quantitation of all analytes were accomplished using multiple reaction monitoring with a minimum of two transitions per analyte. Inter- and intra-accuracy and precision were assessed at four QC concentrations for all analytes (six replicates). The analytes were measured with $\leq 15 \%$ deviation from the expected concentrations for the three highest QC concentrations $(1.5,20$ and $80 \mathrm{ng} / \mathrm{mL})$ and $\leq 15 \%$ coefficient of variation $(\% \mathrm{CV})$. For the lowest QC concentration $(0.6 \mathrm{ng} / \mathrm{mL})$, pregnenolone, $20 \alpha \mathrm{DHP}$ and $3 \beta, 20 \alpha \mathrm{DHP}$ had $\leq 20 \%$ deviation from expected concentrations. The analytes had a percent accuracy (\%Acc) $>90 \%$ and a precision $<15 \%$. The responses were linear and gave correlation coefficients $\left(R^{2}\right)$ of $>0.99$.

\section{In vitro bioactivity assay}

The sequence of the ePGR was determined as described previously (Scholtz et al. 2014) from clones isolated from an equine endometrial expression library and by amplification and sequencing from genomic DNA. The full-length coding sequence was assembled in pcDNA3.1 for the construction and maintenance of a Chinese hamster ovarian $(\mathrm{CHO}$, Eton Bioscience, San Diego, CA, USA) cell line stably expressing the construct under Geneticin selection (Corbin et al. 1999). Briefly, the CHO cells were transfected (Lipofectamine 2000, Invitrogen) with the linearized ePGR expression plasmid, and stably transfected cells were selected by antibiotic resistance (Geneticin, Gibco, $800 \mu \mathrm{g} / \mathrm{mL}$ ) over a period of 3 weeks. Colonies formed by the surviving cells were lifted with filter paper and transferred to new plates for expansion. Realtime PCR was used to confirm the expression in one of the clonal lines in all the subsequent experiments. In the first experiment, this cell line was transfected transiently with an MMTV-luciferase expression plasmid responsive to steroid agonists. Cells were grown for $24 \mathrm{~h}$ and then incubated with increasing concentrations $(0-300 \mathrm{nM})$ of progesterone and two of the most abundant pregnane metabolites present in high concentrations in late gestation mares, $20 \alpha \mathrm{OH}-\mathrm{DHP}$

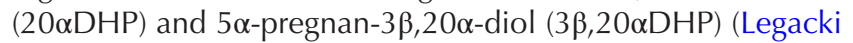
et al. 2016). Luciferase expression was measured $48 \mathrm{~h}$ later to assess progestogenic bioactivity. A second experiment was conducted to measure progestogenic activity of the major pregnane metabolites at their measured peak and half-peak concentrations, consistent with the decline in preparturient concentration. Consequently, cells were incubated with two concentrations of $20 \alpha \mathrm{DHP}(2$ and $1 \mu \mathrm{M}$ ) or $3 \beta, 20 \alpha \mathrm{DHP}$ ( 3 and $1.5 \mu \mathrm{M})$ respectively. The luciferase expression was measured $48 \mathrm{~h}$ later to assess progestogenic bioactivity of these two metabolites at physiologically relevant concentrations.

\section{Statistical analysis}

Analysis of variance was conducted using PROC MIXED with repeated measures in SAS (SAS Statistical Software, SAS Institute Inc, Cary, NC, USA). Location (UCD or UKL) was included as a main effect in the steroid analysis. The significance of differences in steroid concentrations between the designated time points was determined by linear contrasts. Changes in steroids over time were also analyzed with PROC REG to assess linear and quadratic regression models. The correlations among the steroids were determined with PROC CORR. To determine the differences between progesterone receptor responses to the three tested steroids, the data were subjected to PROC MIXED. The relationships between the values at designated concentrations were determined using the interaction between the type of steroid and concentration to perform linear contrasts. To determine linearity of responses, the biopotency data were analyzed using PROC REG procedure. Data that did not meet the standards for normality were log-transformed before analysis. The data were graphed using means and standard errors calculated for each steroid.

\section{Results}

There was no difference in age or gestation periods between the mares sampled at UCD and UKL $(P>0.05)$. The most abundant pregnanes were $3 \beta, 20 \alpha \mathrm{DHP}$

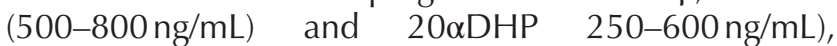
followed by DHP (50-100 ng/mL), allopregnanolone (10-30 ng/mL), pregnenolone $(1.5-4.0 \mathrm{ng} / \mathrm{mL})$ and progesterone $(0.5-2.5 \mathrm{ng} / \mathrm{mL})$. Steroid concentrations varied in the last few days of gestation. Although the steroid concentrations did not fit a simple linear regression model $(P>0.05)$, they fitted a significant quadratic regression model $(P<0.02$; for all except allopregnanolone, $P=0.05)$. Thus, all the measured pregnanes reached a prepartum peak and then declined significantly over the last few days before foaling $(P \leq 0.05)$. The peak was clearly on day -3 for progesterone $(2.1 \pm 0.6 \mathrm{ng} / \mathrm{mL})$, or between days -5 and -3 for other pregnanes. Concentrations of DHP, 3 $3,20 \alpha \mathrm{DHP}$ and allopregnanolone on day -5 were $89.0 \pm 13.3,771.9 \pm 79.6$ and $28.0 \pm 4.5 \mathrm{ng} / \mathrm{mL}$ respectively. Concentrations of pregnenolone and $20 \alpha$ DHP were lower in mares at UCD than those at UKL $(P<0.01)$ - pregnenolone concentration peaked at $2.6 \pm 0.5 \mathrm{ng} / \mathrm{mL}$ on day -4 and $4.3 \pm 1.7 \mathrm{ng} / \mathrm{mL}$ on day -3 respectively. Concentrations of $20 \alpha \mathrm{DHP}$ peaked in mares at UCD, 384.4 $\pm 29.1 \mathrm{ng} / \mathrm{mL}$ on day -7 , and at UKL, $631.9 \pm 157.1 \mathrm{ng} / \mathrm{mL}$ on day -3 , respectively. The decrease in concentrations from peak to the last sample before foaling ranged from 37 to $71 \%$. The concentrations of DHP, allopregnanolone, $3 \beta, 20 \alpha \mathrm{DHP}$ and progesterone dropped on average by 63, 49, 54 and 55\% respectively. 
The concentration of pregnenolone dropped by 52 and $46 \%$ in mares at UCD and UKL respectively, whereas that of $20 \alpha \mathrm{DHP}$ dropped by 28 and $63 \%$ in mares at UCD and UKL respectively. All pregnanes positively correlated with one another.

In vitro bioassay was used for assessing the activation of ePGR. It indicated that all three pregnanes had detectable bioactivity based on significant linear increases in response to the concentrations of progesterone $(P<0.01)$, $20 \alpha \mathrm{DHP}$ and $3 \beta, 20 \alpha \mathrm{DHP}(P<0.05)$, albeit at different levels. The response to progesterone reached a maximum at $30 \mathrm{nM}(<10 \mathrm{ng} / \mathrm{mL})$ of $4.5 \pm 0.9$-fold induction. At the same concentration, $20 \alpha \mathrm{DHP}$ and $3 \beta, 20 \alpha \mathrm{DHP}$ averaged $2.0 \pm 0.4$ - and $1.4 \pm 0.2$-fold activation respectively, which was significantly lower than that of progesterone $(P<0.01)$ but not different from one another. Even at a concentration of $300 \mathrm{nM}$, the average induction of reporter activity was only $2.6 \pm 0.3$ - and $2.0 \pm 0.5$-fold for $20 \alpha \mathrm{DHP}$ and $3 \beta, 20 \alpha \mathrm{DHP}$ respectively. At the prepartum peak and halfpeak concentrations, the activation of ePGR by $20 \alpha \mathrm{DHP}$ ( 2 and $1 \mu \mathrm{M}$ induced $2.89 \pm 0.30$ - and $2.73 \pm 0.02$-fold increases respectively) was higher $(P<0.001)$ than that by $3 \beta, 20 \alpha \mathrm{DHP}$ ( 3 and $1.5 \mu \mathrm{M}$ induced $1.24 \pm 0.05-$ and $1.33 \pm 0.02$-fold increases respectively).

\section{Discussion}

This study is the first to combine daily sampling of blood in periparturient mares with analysis of steroids by mass spectrometry and direct assessment of bioactivity of the dominant pregnanes in vitro. To the best of our knowledge, our steroid profiling includes pregnenolone, the immediate precursor of progesterone and the universal substrate for downstream steroids of all classes (Conley \& Bird 1997, Conley et al. 2011), which has not been measured previously. The results of prior studies on the withdrawal of progestins preceding foaling have been mixed. Some of the earliest reports used chromatography to minimize distortions in steroid estimates due to cross-reaction between the immunoassays subsequently employed, but sampling was infrequent (Barnes et al. 1975, Ganjam et al. 1975, Holtan et al. 1975a,b). A decrease in immunoreactive progesterone (Lovell et al. 1975, Seren et al. 1981) and DHP (Hamon et al. 1991) concentrations was noted by those using daily sampling but without chromatography. Although not statistically significant, the data associated with more frequent sampling (followed by immunoassay without chromatography) indicated that concentrations may drop only during the last 12 (Pope et al. 1987) or $28 \mathrm{~h}$ (Haluska \& Currie 1988). Progesterone was separated from DHP and hydroxyl-5 $\alpha$-pregnanones using chromatography by those who sampled mares twice each day, reporting that DHP decreased from $80 \mathrm{~h}$ before foaling but in no case did (progesterone) levels fall before parturition' (Seamans et al. 1979). The results of those studies are in accordance with the estimates of $5 \alpha$-pregnanes reported here with respect to timing, indicating that concentrations peak at 3 days before foaling (day -3) and decline thereafter. Moreover, these data suggest that all pregnane concentrations decrease in mares in the immediate prepartum period.

Thelandmarkstudies of Holtan and coworkers provided foundational data on systemic pregnane concentrations throughout equine pregnancy - some of which are extraordinarily high during late gestation though their bioactivity and significance are unknown. Specifically, they reported that concentrations of individual DHP metabolites approach $1 \mu \mathrm{g} / \mathrm{mL}$ in some mares (Holtan et al. 1991). The concentrations of $5 \alpha$-reduced pregnane exceeded $1 \mu \mathrm{g} / \mathrm{mL}$, consistent with the total concentrations of immunoreactive pregnanes reported by others (Seamans et al. 1979). These concentrations are remarkable, even by the standards of human pregnancy (Hill et al. 2007). This study confirms that the major metabolites identified by Holtan and coworkers (1991) are $20 \alpha \mathrm{DHP}$ and $3 \beta, 20 \alpha \mathrm{DHP}$, although the latter had the highest concentration in our analysis. Consistent with the lack of bioactivity suggested by competitive binding assays of progesterone in incubations with tissue extracts (Jewgenow \& Meyer 1998, Chavatte-

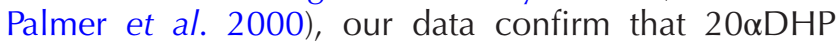
and $3 \beta, 20 \alpha \mathrm{DHP}$ are relatively inactive metabolites of DHP. Previous studies (Jewgenow \& Meyer 1998,

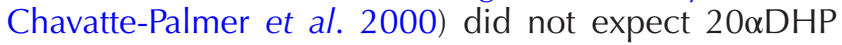
or $3 \beta, 20 \alpha \mathrm{DHP}$ to exhibit significant progestogenic bioactivity compared with progesterone. Many factors activate steroid receptors, which typically occurs in a tissue- and cell-selective fashion due to expression levels of receptor (Abd-Elnaeim et al. 2009) and coregulator (Knutti et al. 2000), chromatin accessibility (Wiench et al. 2011, Grontved \& Hager 2012), as well as local steroid metabolism (Funder et al. 1988). The functions of steroid hormone response elements are influenced by both genetic sequence and chromatin structure. However, the MMTV promoter in a useful for modeling the steroid hormone response (Adom et al. 1991, Truss et al. 1992, McNally et al. 2000, Nagaich et al. 2004, Vicent et al. 2010, Wiench et al. 2011). Chinese hamster ovarian $(\mathrm{CHO})$ cells are not the ideal vehicle to explore the bioactivation of progesterone receptors by potential agonists, although even yeast-based assays have been utilized successfully and extensively (McRobb et al. 2008). Primary cell cultures of equine endometrial epithelium, myometrium or mammary glandular epithelium could provide a better physiological cell model if they retained responsiveness in vitro. Previous attempts using equine tissues in vitro have not provided satisfactory results (Ousey et al. 2000). Despite their heterologous nature, with respect to species of cells and constructs (mix of hamster, mouse, equine and human), previous studies introducing constructs including MMTV-driven luciferase along with equine and human progesterone receptor sequences into HepG2 cells 

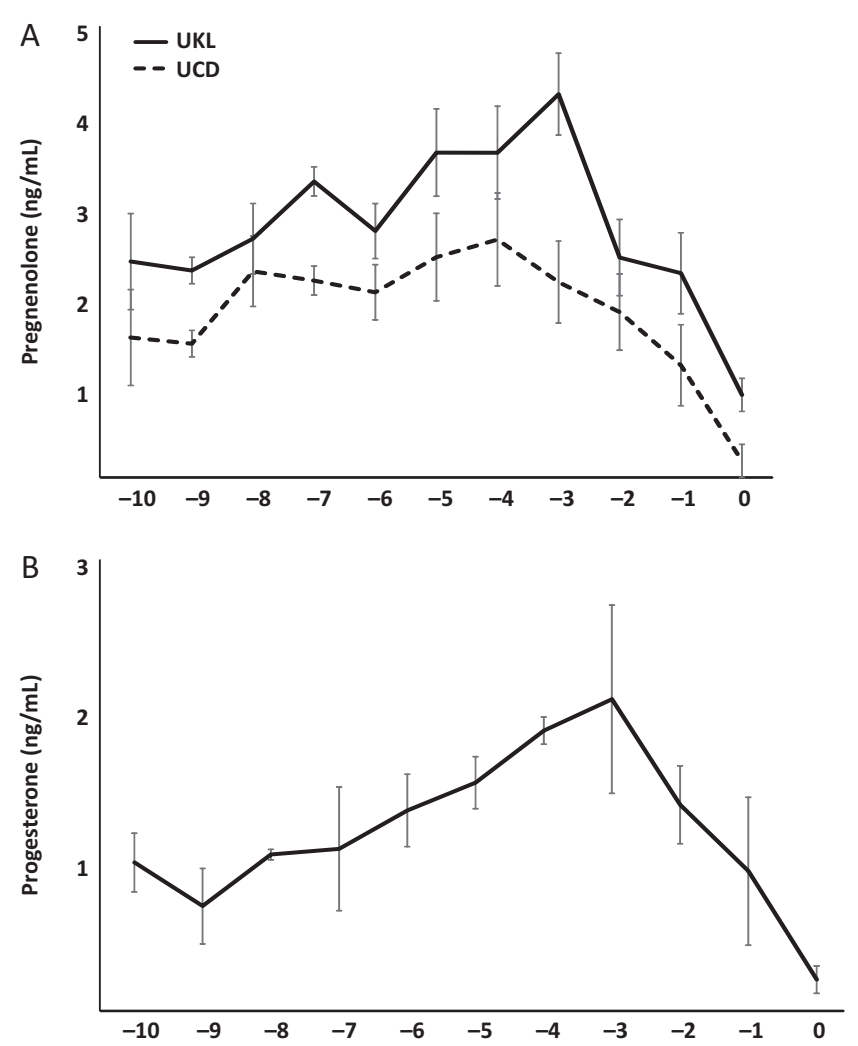

Figure 1 Concentrations $(\mathrm{ng} / \mathrm{mL}$ ) of pregnenolone $(A)$ and progesterone (B) in serum of periparturient mares sampled at two different institutions (UKY, $n=3$, solid line; UCD, $n=4$, dotted line) over the last 10 days of gestation (day 0 is the day of foaling). (A) Pregnenolone concentrations were lower in mares at UCD $(n=4)$ than those in mares at UKY $(n=3 ; P<0.01)$. Pregnenolone concentrations peaked on day -4 at UCD or day -3 at UKY and significantly declined by day $-1(P<0.01)$ (B) Progesterone concentrations were similar among mares at UKY and UCD, so data were combined. Progesterone declined significantly from day -3 to $-1(P=0.02)$. Data represent mean \pm S.E.M.

were successful in detecting species-specific differences in responses to DHP that accorded well with in vivo responses to DHP in mares (Scholtz et al. 2014). Thus, the bioactivity of the equine progesterone receptor in $\mathrm{CHO}$ cells likely represents a useful screening assay for progestogenic activity of pregnane metabolites circulating in mares in late gestation.

Given the above-mentioned caveats of assessing bioactivity in vitro, the results presented here extend our prior observations on biopotency of $5 \alpha$-reduced metabolites, allowing an estimate of the potential contribution of all these pregnanes to ePGR activation at peak concentrations in prepartum mares. Progesterone peaked at $2 \mathrm{ng} / \mathrm{mL}(<6 \mathrm{nM})$, a concentration expected to induce a half-maximal ePGR activation based on the in vitro data. As previous studies in our laboratory demonstrated that DHP was equipotent with progesterone (Scholtz et al. 2014), prepartum peak DHP concentration $(89.0 \mathrm{ng} / \mathrm{mL}$ or $28 \mathrm{nM})$ likely exerts maximal progestogenic activation of the ePGR.
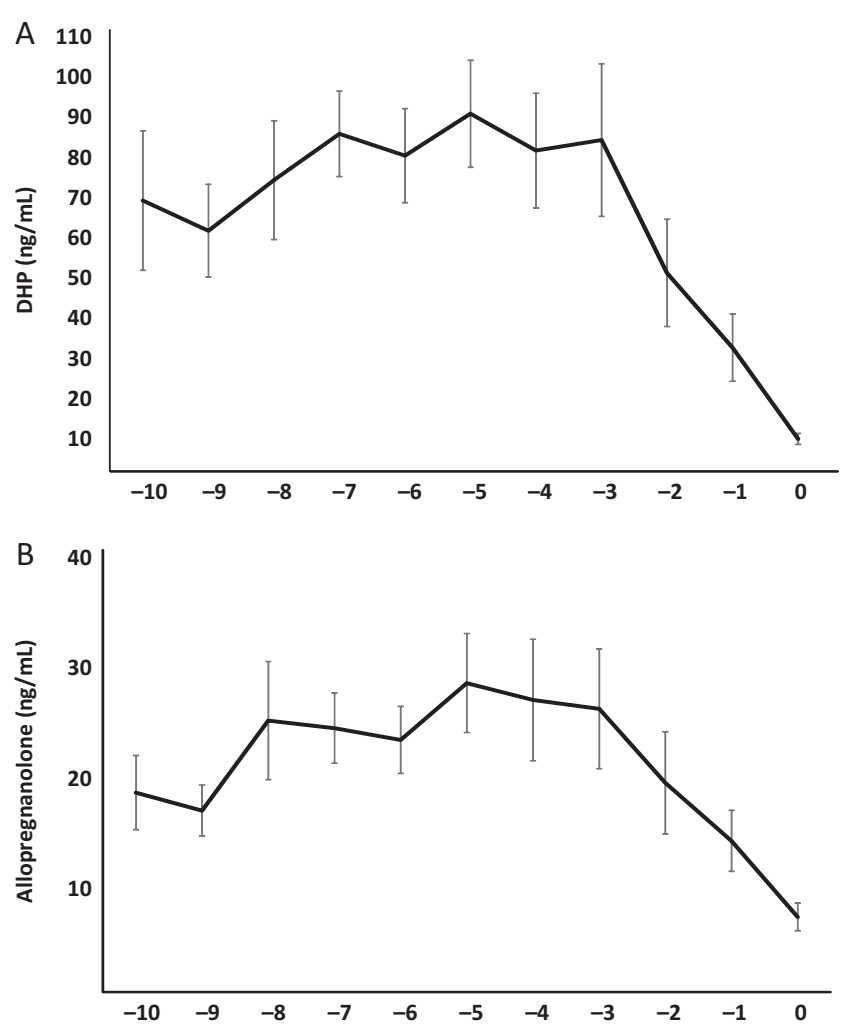

Figure 2 Concentrations $(\mathrm{ng} / \mathrm{mL})$ of $5 \alpha$-reduced pregnanes, dihydroprogesterone (DHP, A) and allopregnanolone (B) in serum of periparturient mares sampled at two different institutions (UKY and $\mathrm{UCD})$ over the last 10 days of gestation in mares $(n=7$, day 0 is day of foaling). DHP $(P<0.01, \mathrm{~A})$ and allopregnanolone $(P=0.05, \mathrm{~B})$ concentrations both declined significantly from day -5 to -1 .

Data represent mean \pm S.E.M.

Extrapolating from the maximal concentrations used

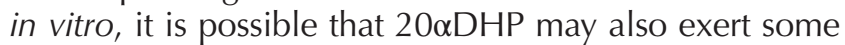
progestogenic influence, at least in the absence of DHP or progesterone. In this regard, the decline in $20 \alpha \mathrm{DHP}$ may have relevance in terms of progestin withdrawal. Although the progestin withdrawal occurs systemically days before foaling, this may not be the sole mechanism that leads to parturition. That other mechanisms may operate to decrease progestogenic influence at parturition is suggested by the observation that DHP and $20 \alpha$-DHP exhibited significant activation of the ePGR at concentrations approximating those seen the day before foaling. Although the concentrations decline steadily on the day preceding foaling, they were still high enough to exert progestogenic influence based on in vitro bioactivity. In addition, altrenogest administration can sustain pregnancy in ovariectomized embryo-recipient mares (Hinrichs et al. 1986, McKinnon et al. 1988). However, at twice the dose, it was not able to delay parturition (Neuhauser et al. 2008). This suggests that changes in ePGR expression or the ability of progestins to maintain progestogenic influence in the reproductive tract decrease around foaling regardless of changes in circulating pregnane concentrations. Thus, there is a 

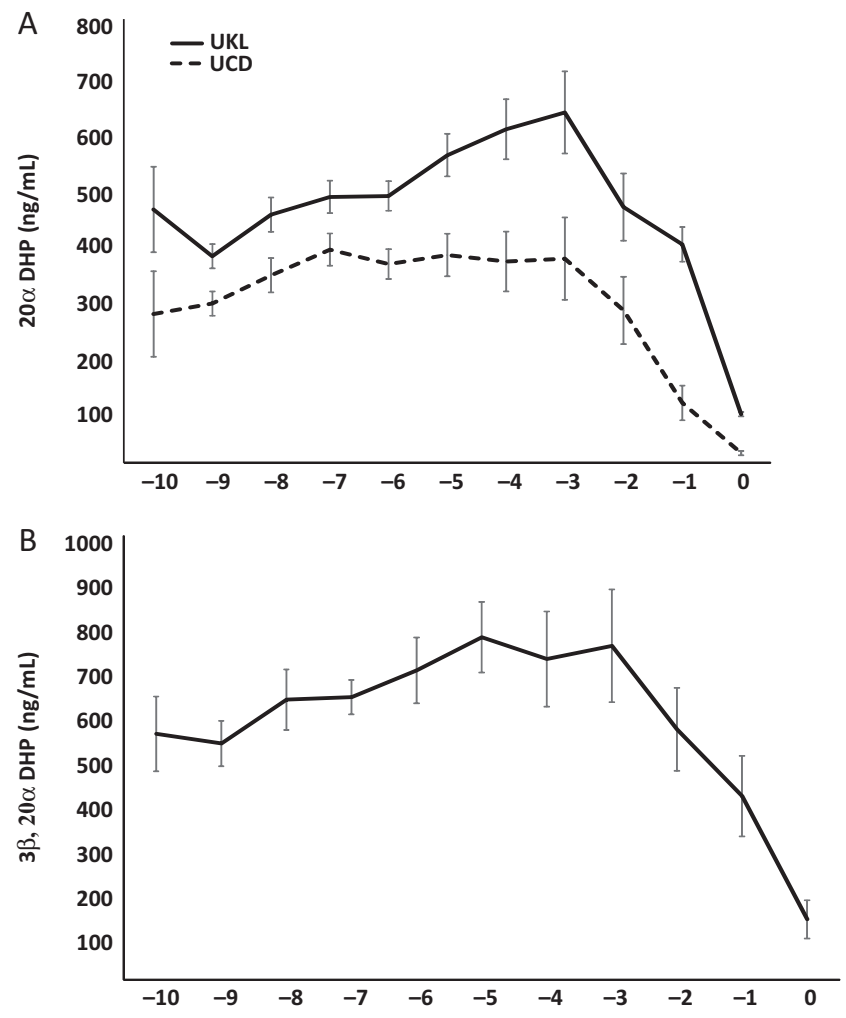

Figure 3 Concentrations $(\mathrm{ng} / \mathrm{mL})$ of metabolites of DHP, $20 \alpha$-dihydroprogesterone (20 $\alpha \mathrm{DHP}, \mathrm{A})$ and $3 \beta, 20 \alpha-$ dihydroprogesterone $(3 \beta, 20 \alpha \mathrm{DHP}, \mathrm{B})$ measured in serum of periparturient mares sampled at two different institutions (UKY, $n=3$, solid line; UCD, $n=4$, dotted line) over the last 10 days of gestation (day 0 is the day of foaling). $20 \alpha \mathrm{DHP}$ concentrations peaked on day -7 at UCD or day -3 at UKY and both significantly declined by day $-1(P<0.01)(\mathrm{A})$ Concentrations of $20 \alpha \mathrm{DHP}$ in mares at UCD $(n=4)$ were lower than those in mares at UKY $(n=3 ; P<0.01)$.

(B) Concentrations of $3 \beta, 20 \alpha \mathrm{DHP}$ were similar among mares at UKY and UCD, so data were combined. Concentrations of $3 \beta, 20 \alpha D H P$ declined significantly from day -5 to $-1(P<0.01)$. Data represent mean \pm S.E.M.

locally regulated mechanism of progestin withdrawal at parturition in mares (Conley 2016), even though pregnane concentrations decline prepartum as described here.

Despite their relative lack of biopotency compared with DHP and progesterone, the authors believe that the collapse of secretion of the most abundant of the $5 \alpha$-reduced pregnanes late in equine gestation does have significance. As in sheep (Casida \& Warwick 1945) and humans (Asdell 1928), some equine pregnancies can continue without luteal support (after ovariectomy) as early as day 55 of gestation, most mares after day 70 (Holtan et al. 1979). Hence, all circulating pregnanes in the second half of pregnancy in the mare are presumed to be of placental origin, consistent with the results of other in vivo and in vitro studies (Moss et al. 1979, Hamon et al. 1991). Thus, the decline in all pregnanes before parturition in the mare, no matter what the time frame, suggests that placental synthesis itself begins to decline. The present data clearly indicate
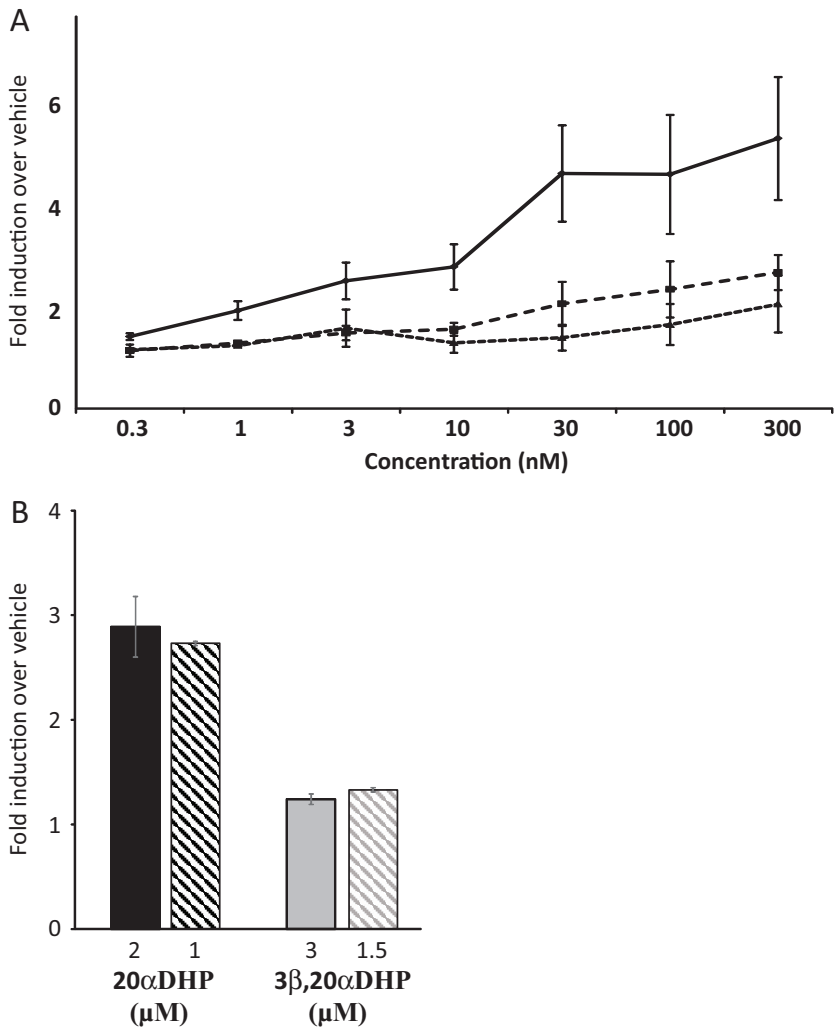

Figure 4 Concentration-dependent progestogenic bioactivation of the equine progesterone receptor (ePGR) by progesterone and the pregnane metabolites, $20 \alpha$-dihydroprogesterone $(20 \alpha \mathrm{DHP})$ and $3 \beta, 20 \alpha$-dihydroprogesterone $(3 \beta, 20 \alpha \mathrm{DHP})$, measured by stimulated (fold induction over vehicle) luciferase expression and activity driven by the mouse mammary tumor virus (MMTV) promoter. (A) Relative progestogenic bioactivity at increasing pregnane concentrations (0.3-300 nM). Progesterone (solid), 20 $\mathrm{DHP}$ (dashed) and $3 \beta, 20 \alpha \mathrm{DHP}$ (dotted) exhibited detectable bioactivity with increasing concentrations of progesterone $(P<0.01)$, and of $20 \alpha \mathrm{DHP}$ and $3 \beta, 20 \alpha \mathrm{DHP}(P<0.05)$, which is significantly less than that of progesterone. (B) Measured bioactivation of the ePGR by $20 \alpha \mathrm{DHP}$ ( 2 and $1 \mu \mathrm{M}$ ) and $3 \beta, 20 \alpha \mathrm{DHP}(3$ and $1.5 \mu \mathrm{M}$ ) representing prepartum peak and half-peak concentrations respectively. Bioactivation of

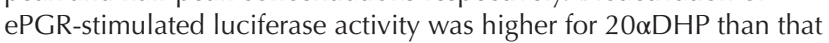
for $3 \beta, 20 \alpha \mathrm{DHP}$ at both peak and half-peak $(P<0.001)$. Data represent mean \pm S.E.M ( $n=5$ replicates).

for the first time that a decrease in pregnenolone concentrations in the maternal circulation plays an important role. There is convincing evidence that the equine placenta receives pregnenolone from the fetal foal (Ousey et al. 2003), although the site of synthesis in the fetus, adrenal cortex, gonad or other organ is unclear (Conley 2016). A peripartum decline in maternal pregnenolone concentrations implies that there may be a decrease in the supply of pregnenolone from the fetus or in the ability of the placenta itself to synthesize it, however small that contribution may be. Cortisol synthesis in the equine fetus increases at term (Silver \& Fowden 1994, Cudd et al. 1995, Fowden et al. 2008) concomitant with the decrease in concentrations of pregnenolone and other pregnanes based on the 
data presented here. It is difficult to reconcile these apparently opposing trends in steroid secretion if the fetal adrenal cortex were the source of pregnenolone. Chavatte and coworkers investigated $3 \beta \mathrm{HSD}$ in late gestation and term equine placentas, but the reported activities were highly variable and no difference was detected between them (Chavatte et al. 1995). No other studies have investigated the enzyme activities associated with pregnane synthesis in the equine placenta before and at parturition. Such studies are of great importance, especially in species like the horse, where progestin withdrawal involves a decrease in the most abundant circulating pregnanes as well pregnenolone before foaling.

The significantly lower concentrations of

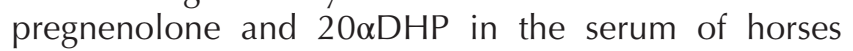
sampled at UCD compared with UKL was unexpected and warrants comment. These were the only locationdependent differences observed, which could not be explained by age or gestation period. These were similar in the mares at each site, although breeds and years of sample collection clearly differed. By immunoassay, Hamon and coworkers reported that DHP concentrations in thoroughbred mares were twice those seen in ponies in late gestation (Hamon et al. 1991). However, the authors of this study are unable to posit how breed might affect the concentrations of pregnenolone and $20 \alpha \mathrm{DHP}$ but not those of other pregnanes. Pregnenolone, the lowest concentration of the measured pregnanes, and $20 \mathrm{a}[\alpha] \mathrm{DHP}$, the highest, also represent the extremes of the metabolic cascade in terms initiating substrate (pregnenolone) and end product $(20 \alpha \mathrm{DHP}$; Fig. 1). Yet, no other intermediate pregnane measured differed significantly or was even close to reaching significance. Further studies are necessary to verify the validity of this result, which might otherwise simply represent a type 1 statistical error. Regardless of the apparent difference in these two steroids in the two groups of mares, the pattern of prepartum decline was the same for all the examined pregnanes (Figs 1, 2, 3 and 4).

In summary, the data reported herein demonstrate that there is a general decline in the concentrations of pregnanes, including pregnenolone, 2 or 3 days before foaling in parturient mares. The authors theorize that progestin withdrawal associated with the initiation of parturition in horses involves an arrest of pregnane synthesis. Further studies are necessary to determine the molecular basis behind the apparent prepartum termination of pregnane synthesis in the mare.

\section{Declaration of interest}

The authors declare that there is no conflict of interest that could be perceived as prejudicing the impartiality of the research reported.

\section{Funding}

This work was supported by the John P Hughes Endowment and the School of Veterinary Medicine, University of California, Davis, CA, USA, and the Albert G Clay Endowment, University of Kentucky, Lexington, KY, USA. The funders had no role in the study design, data collection and analysis, decision to publish, or preparation of the manuscript. The authors wish to acknowledge the generous support of John P Hughes and Albert G Clay Endowments that funded these studies.

\section{Acknowledgements}

The sampling of mares at the University of California, Davis was conducted by Joel Viloria and the undergraduate students from the Department of Animal Science, without whose help these studies could not have been completed. The authors also wish to express their gratitude to the technical staff at the Equine Analytical Chemistry Laboratory, School of Veterinary Medicine, University of California, Davis, especially Daniel McKemie, Teresa Bowers, Go Sugiarto and Sandy Yim for the efforts and support in providing expertise, training, technical support and guidance for analysis of samples by liquid chromatography-tandem mass spectroscopy.

\section{References}

Abd-Elnaeim MM, Derar IR, Wilsher S, Allen WR, Leiser R \& Schuler G 2009 Immunohistochemical localization of oestrogen receptors alpha and beta, progesterone receptor and aromatase in the equine placenta. Reproduction in Domestic Animals 44 312-319. (doi:10.1111/j.14390531.2008.01073.x)

Adom J, Carr KD, Gouilleux F, Marsaud V \& Richard-Foy H 1991 Chromatin structure of hormono-dependent promoters. Journal of Steroid Biochemistry and Molecular Biology 40 325-332. (doi:10.1016/09600760(91)90198-E)

Asdell SA 1928 The growth and function of the corpus luteum. Physiological Reviews 8 313-345.

Barnes RJ, Nathanielsz PW, Rossdale PD, Comline RS \& Silver M 1975 Plasma progestagens and oestrogens in fetus and mother in late pregnancy. Journal of Reproduction and Fertility. Supplement 23 617-623.

Casida LE \& Warwick EJ 1945 The necessity of the corpus luteum for maintenance of pregnancy in the ewe. Journal of Animal Science 4 $34-36$.

Chavatte-Palmer P, Duchamp G, Palmer E, Ousey JC, Rossdale PD \& Lombes M 2000 Progesterone, oestrogen and glucocorticoid receptors in the uterus and mammary glands of mares from mid- to late gestation. Journal of Reproduction and Fertility. Supplement 56 661-672.

Chavatte PM, Rossdale PD \& Tait AD 1995 Modulation of 3 betahydroxysteroid dehydrogenase ( 3 beta-HSD) activity in the equine placenta by pregnenolone and progesterone metabolites. Equine Veterinary Journal 27 342-347. (doi:10.1111/j.2042-3306.1995.tb04068.x )

Condon JC, Jeyasuria P, Faust JM, Wilson JW \& Mendelson CR 2003 A decline in the levels of progesterone receptor coactivators in the pregnant uterus at term may antagonize progesterone receptor function and contribute to the initiation of parturition. PNAS 100 9518-9523. (doi:10.1073/pnas.1633616100)

Conley AJ 2016 Review of the reproductive endocrinology of the pregnant and parturient mare. Theriogenology 86 355-365. (doi:10.1016/j. theriogenology.2016.04.049)

Conley AJ \& Bird IM 1997 The role of cytochrome P450 17 alphahydroxylase and 3 beta-hydroxysteroid dehydrogenase in the integration of gonadal and adrenal steroidogenesis via the delta 5 and delta 4 pathways of steroidogenesis in mammals. Biology of Reproduction $\mathbf{5 6}$ 789-799. (doi:10.1095/biolreprod56.4.789) 
Conley AJ \& Neto ACA 2008 The ontogeny of fetal adrenal steroidogenesis as a prerequisite for the initiation of parturition. Experimental and Clinical Endocrinology \& Diabetes 116 385-392. (doi:10.1055/s-2008-1076713)

Conley AJ \& Reynolds LP 2014 Steroidogenesis and the initiation of parturition. In Reproduction in Domestic Ruminants, pp 399-413. Eds JL Juengel, A Miyamoto, C Price, LP Reynolds, MF Smith \& R Webb. London, UK: Society for Reproduction and Fertility.

Conley AJ, Corbin CJ, Thomas JL, Gee NA, Lasley BL, Moeller BC, Stanley SD \& Berger T 2011 Costs and consequences of cellular compartmentalization and substrate competition among human enzymes involved in androgen and estrogen synthesis. Biology of Reproduction 86 1-8. (doi:10.1095/biolreprod.111.094706)

Conneely OM, Mulac-Jericevic B \& Lydon JP 2003 Progesteronedependent regulation of female reproductive activity by two distinct progesterone receptor isoforms. Steroids 68 771-778. (doi:10.1016/ S0039-128X(03)00126-0)

Corbin CJ, Trant JM, Walters KW \& Conley AJ 1999 Changes in testosterone metabolism associated with the evolution of placental and gonadal isozymes of porcine aromatase cytochrome P450. Endocrinology $\mathbf{1 4 0}$ 5202-5210. (doi:10.1210/en.140.11.5202)

Cudd TA, Leblanc M, Silver M, Norman W, Madison J, Keller-Wood M \& Wood CE 1995 Ontogeny and ultradian rhythms of adrenocorticotropin and cortisol in the late-gestation fetal horse. Journal of Endocrinology 144 271-283. (doi:10.1677/joe.0.1440271)

Fowden AL, Forhead AJ \& Ousey JC 2008 The endocrinology of equine parturition. Experimental and Clinical Endocrinology \& Diabetes 116 393-403. (doi:10.1055/s-2008-1042409)

Funder JW, Pearce PT, Smith R \& Smith AI 1988 Mineralocorticoid action: target tissue specificity is enzyme, not receptor, mediated. Science $\mathbf{2 4 2}$ 583-585. (doi:10.1126/science.2845584)

Ganjam VK, Kenney RM \& Flickinger G 1975 Plasma progestagens in cyclic, pregnant and post-partum mares. Journal of Reproduction and Fertility. Supplement 23 441-447.

Grontved L \& Hager GL 2012 Impact of chromatin structure on PR signaling: transition from local to global analysis. Molecular and Cellular Endocrinology 357 30-36. (doi:10.1016/j.mce.2011.09.006)

Haluska GJ \& Currie WB 1988 Variation in plasma concentrations of oestradiol-17 beta and their relationship to those of progesterone, 13,14-dihydro-15-keto-prostaglandin F-2 alpha and oxytocin across pregnancy and at parturition in pony mares. Journal of Reproduction and Fertility 84 635-646. (doi:10.1530/jrf.0.0840635)

Hamon M, Clarke SW, Houghton E, Fowden AL, Silver M, Rossdale PD, Ousey JC \& Heap RB 1991 Production of 5 alpha-dihydroprogesterone during late pregnancy in the mare. Journal of Reproduction and Fertility. Supplement 44 529-535.

Hill M, Cibula D, Havlikova H, Kancheva L, Fait T, Kancheva R, Parizek A \& Starka L 2007 Circulating levels of pregnanolone isomers during the third trimester of human pregnancy. Journal of Steroid Biochemistry and Molecular Biology 105 166-175. (doi:10.1016/j.jsbmb.2006.10.010)

Hinrichs K, Sertich PL \& Kenney RM 1986 Use of altrenogest to prepare ovariectomized mares as embryo transfer recipients. Theriogenology $\mathbf{2 6}$ 455-460. (doi:10.1016/0093-691X(86)90037-3)

Holtan DW, Nett TM \& Estergreen VL 1975a Plasma progestagens in pregnant mares. Journal of Reproduction and Fertility. Supplement 23 419-424.

Holtan DW, Nett TM \& Estergreen VL 1975b Plasma progestins in pregnant, postpartum and cycling mares. Journal of Animal Science $\mathbf{4 0}$ 251-260.

Holtan DW, Squires EL, Lapin DR \& Ginther OJ 1979 Effect of ovariectomy on pregnancy in mares. Journal of Reproduction and Fertility. Supplement 27 457-463.

Holtan DW, Houghton E, Silver M, Fowden AL, Ousey J \& Rossdale PD 1991 Plasma progestagens in the mare, fetus and newborn foal. Journal of Reproduction and Fertility. Supplement 44 517-528.

Jenkin G \& Young IR 2004 Mechanisms responsible for parturition; the use of experimental models. Animal Reproduction Science 82-83 567-581. (doi:10.1016/j.anireprosci.2004.05.010)

Jewgenow K \& Meyer HH 1998 Comparative binding affinity study of progestins to the cytosol progestin receptor of endometrium in different mammals. General and Comparative Endocrinology 110 118-124. (doi:10.1006/gcen.1997.7054)

Kastner P, Krust A, Turcotte B, Stropp U, Tora L, Gronemeyer H \& Chambon P 1990 Two distinct estrogen-regulated promoters generate transcripts encoding the two functionally different human progesterone receptor forms A and B. EMBO Journal 9 1603-1614.

Knutti D, Kaul A \& Kralli A 2000 A tissue-specific coactivator of steroid receptors, identified in a functional genetic screen. Molecular and Cellular Biology 20 2411-2422. (doi:10.1128/MCB.20.7.24112422.2000)

Legacki EL, Scholtz EL, Ball BA, Stanley SD, Berger T \& Conley AJ 2016 The dynamic steroid landscape of equine pregnancy mapped by mass spectrometry. Reproduction 151 421-430. (doi:10.1530/REP-15-0547)

Lovell JD, Stabenfeldt GH, Hughes JP \& Evans JW 1975 Endocrine patterns of the mare at term. Journal of Reproduction and Fertility. Supplement 23 449-456.

McKinnon AO, Squires EL, Carnevale EM \& Hermenet MJ 1988 Ovariectomized steroid-treated mares as embryo transfer recipients and as a model to study the role of progestins in pregnancy maintenance. Theriogenology 29 1055-1063. (doi:10.1016/S0093-691X(88)80029-3)

McNally JG, Muller WG, Walker D, Wolford R \& Hager GL 2000 The glucocorticoid receptor: rapid exchange with regulatory sites in living cells. Science 287 1262-1265. (doi:10.1126/science.287.5456.1262)

McRobb L, Handelsman DJ, Kazlauskas R, Wilkinson S, McLeod MD \& Heather AK 2008 Structure-activity relationships of synthetic progestins in a yeast-based in vitro androgen bioassay. Journal of Steroid Biochemistry and Molecular Biology 110 39-47. (doi:10.1016/j. jsbmb.2007.10.008)

Mendelson CR \& Condon JC 2005 New insights into the molecular endocrinology of parturition. Journal of Steroid Biochemistry and Molecular Biology 93 113-119. (doi:10.1016/j.jsbmb.2004.12.027)

Mesiano S, Wang Y \& Norwitz ER 2011 Progesterone receptors in the human pregnancy uterus: do they hold the key to birth timing? Reproductive Sciences 18 6-19. (doi:10.1177/1933719110382922)

Mitchell BF \& Taggart MJ 2009 Are animal models relevant to key aspects of human parturition? American Journal of Physiology: Regulatory, Integrative and Comparative Physiology 297 R525-R545. (doi:10.1152/ ajpregu.00153.2009)

Moss GE, Estergreen VL, Becker SR \& Grant BD 1979 The source of the 5-alpha-pregnanes that occur during gestation in mares. Journal of Reproduction and Fertility. Supplement 27 511-519.

Nagaich AK, Rayasam GV, Martinez ED, Becker M, Qiu Y, Johnson TA, Elbi C, Fletcher TM, John S \& Hager GL 2004 Subnuclear trafficking and gene targeting by steroid receptors. Annals of the New York Academy of Sciences 1024 213-220. (doi:10.1196/annals.1321.002)

Nathanielsz PW 1998 Comparative studies on the initiation of labor. European Journal of Obstetrics \& Gynecology and Reproductive Biology 78 127-132. (doi:10.1016/S0301-2115(98)00058-X)

Neuhauser S, Palm F, Ambuehl F \& Aurich C 2008 Effects of altrenogest treatment of mares in late pregnancy on parturition and on neonatal viability of their foals. Experimental and Clinical Endocrinology \& Diabetes 116 423-428. (doi:10.1055/s-2008-1065367)

Norwitz ER 1999 The initiation of parturition: a comparative analysis across species. Current Problems in Obstatrics, Gynecology and Fertility 2 46-71.

Ousey JC, Freestone N, Fowden AL, Mason WT \& Rossdale PD 2000 The effects of oxytocin and progestagens on myometrial contractility in vitro during equine pregnancy. Journal of Reproduction and Fertility. Supplement $\mathbf{5 6}$ 681-691.

Ousey JC, Forhead AJ, Rossdale PD, Grainger L, Houghton E \& Fowden AL 2003 Ontogeny of uteroplacental progestagen production in pregnant mares during the second half of gestation. Biology of Reproduction 69 540-548. (doi:10.1095/biolreprod.102.013292)

Pieber D, Allport VC, Hills F, Johnson M \& Bennett PR 2001 Interactions between progesterone receptor isoforms in myometrial cells in human labour. Molecular Human Reproduction 7 875-879. (doi:10.1093/ molehr/7.9.875)

Pope NS, Sargent GF, Wiseman BS \& Kesler DJ 1987 Transitory changes of hormones in the plasma of parturient pony mares. Journal of Reproduction and Fertility. Supplement 35 629-634.

Renthal NE, Williams KC, Montalbano AP, Chen CC, Gao L \& Mendelson CR 2015 Molecular regulation of parturition: a myometrial perspective. Cold Spring Harbor Perspectives in Medicine 5 a023069. (doi:10.1101/cshperspect.a023069)

Scholtz EL, Krishnan S, Ball BA, Corbin CJ, Moeller BC, Stanley SD, McDowell KJ, Hughes AL, McDonnell DP \& Conley AJ 2014 Pregnancy without progesterone in horses defines a second endogenous biopotent 
progesterone receptor agonist, 5alpha-dihydroprogesterone. PNAS 111 3365-3370. (doi:10.1073/pnas.1318163111)

Seamans KW, Harms PG, Atkins DT \& Fleeger JL 1979 Serum levels of progesterone, 5 alpha-dihydroprogesterone and hydroxy-5 alphapregnanones in the prepartum and postpartum equine. Steroids 33 55-63. (doi:10.1016/S0039-128X(79)80006-9)

Seren E, Tamanini C, Gaiani R \& Bono G 1981 Concentrations of progesterone, 17 alpha-hydroxyprogesterone and 20 alphadihydroprogesterone in the plasma of mares during pregnancy and at parturition. Journal of Reproduction and Fertility 63 443-448. (doi:10.1530/jrf.0.0630443)

Short RV 1959 Progesterone in blood. IV. Progesterone in the blood of mares. Journal of Endocrinology 19 207-210. (doi:10.1677/ joe.0.0190207)

Silver M 1994 Placental progestagens in the sheep and horse and the changes leading to parturition. Experimental and Clinical Endocrinology 102 203-211. (doi:10.1055/s-0029-1211284)

Silver M \& Fowden AL 1994 Prepartum adrenocortical maturation in the fetal foal: responses to ACTH. Journal of Endocrinology 142 417-425. (doi:10.1677/joe.0.1420417)

Smith R 2007 Parturition. New England Journal of Medicine 356 271-283. (doi:10.1056/NEJMra061360)

Thorburn GD 1993 A speculative review of parturition in the mare. Equine Veterinary Journal. Supplement 14 41-49. (doi:10.1111/ j.2042-3306.1993.tb04808.x)
Thorburn GD \& Challis JR 1979 Endocrine control of parturition. Physiological Reviews 59 863-918.

Truss M, Chalepakis G \& Beato M 1992 Interplay of steroid hormone receptors and transcription factors on the mouse mammary tumor virus promoter. Journal of Steroid Biochemistry and Molecular Biology 43 365-378. (doi:10.1016/0960-0760(92)90071-P)

Vicent GP, Nacht AS, Zaurin R, Ballare C, Clausell J \& Beato M 2010 Minireview: role of kinases and chromatin remodeling in progesterone signaling to chromatin. Molecular Endocrinology 24 2088-2098. (doi:10.1210/me.2010-0027)

Wiench M, Miranda TB \& Hager GL 2011 Control of nuclear receptor function by local chromatin structure. FEBS Journal 278 2211-2230. (doi:10.1111/j.1742-4658.2011.08126.x)

Zakar T \& Hertelendy F 2007 Progesterone withdrawal: key to parturition. American Journal of Obstetrics and Gynecology 196 289-296. (doi:10.1016/j.ajog.2006.09.005)

Received 26 April 2016

First decision 30 May 2016

Revised manuscript received 17 June 2016

Accepted 18 July 2016 